\title{
The Knowledge Society and the Social Capacity: A Proposal
}

\author{
B. Peña-Acuña \\ Catholic University of Saint Anthony, Murcia, Spain
}

\begin{abstract}
In this dissertation we pretend to revise authors, concepts and theories of social and emotional capacity in order to highlight a model that would be need to be implemented in Education and other areas. The methodology has consisted on a theoretical and research revision and research done before on emotional and social intelligence in Education and Business Areas. Also it has been made previously a study of Society of Knowledge from Communication's theory and a theoretical and practical revision of the educative model of Bolony implemented in Europe since 2.000. We propose a educative model psycho-social that fits perfectly with the Knowledge society and News Technologies, the society we are living in and it could give it an added value of humanity and more economic efficacy.
\end{abstract}

KEYWORD: psycho-social model; emotional intelligence; social intelligence; social styles; social skills

\section{INTRODUCTION}

Aristotle in the $\mathrm{V}$ century $\mathrm{BC}$ said a fundamental anthropological truth: the man whose appearance is so individual is as well so social. However, both aspects of man's nature are still under scientific study.

\section{CONCEPTS, THEORIES AND AUTHORS}

The theories in the social field from Psychology, Sociology and Business of the Anglo-Saxon culture have enriched in recent decades this old theory, so that if all of them are combined they build a profiled psychosocial model and allow a thorough investigation into this human aspect, because they provide lots a way and lighting to this aspect that highlighted the Greek sage so many centuries ago precisely because knowledge was a Well that was built and shared through dialogue with other provident scholars. These main theories chosen will be presented chronologically in a line with others. All of them provide us with different shades of the same reality and coincide recognizing social intelligence and variables about it.

\subsection{Last Century authors}

From the Psychology Edward L. Thorndike (1920) in their day stresses that there is a type of interpersonal intelligence and ability to understand and motivate people. This author inspire others authors. In 1936, another American author, Dale Carnegie (1936) wrote a book that would be a best seller "How to Win Friends and Influence People", a practical manual on how to treat others where Abraham Lincoln represents with facts many social qualities practices. This book has enriched popular culture about social behavior and it is considered a classic about the issue.

Since the mid-1970s in the business world talking about the social skills to achieve greater self-esteem and social development, there are highlighted namely four types: first, basic skills: active listening, assertive communication, etc.; second, advanced skills: convincing, order or give an instruction, etc.; third, aimed at expressing feelings skills; fourth, alternatives to aggression skills: sharing, asking permission, help, negotiate, etc. There are many studies about social skills till know in many fields as Business and other professions that require contact with people.

Among other theories, social skills are based on Albert Bandura's theory about the social learning that occurs by direct and positive reinforcement of skills, vicarious learning or observational learning through the development of cognitive expectations of interpersonal situations and interpersonal feedback. Bandura is accepted as a classic author in Education, as it could be Piaget, and he has inspired many educative programs. Also based on the 
explanatory model of Michael Argyle and Adam Kendon (1967) whose main element is the role, in which the motor behavior, perceptual and cognitive processes are integrated mechanisms.

Dr. David W. Merrill and Dr. Roger Reid (1981) began research on social styles to create a model that could predict success in sales and management career serving four aspects: style of communication, assertiveness, empathy and flexibility. These researchers found that people can be classified reliably in a few specific types based on their social behavior and tasks. The original Social Styles model was developed by Dr. James W. Taylor, personal psychologist Martin Corporation in Denver. Dr. Merrill obtained the rights to use the model of social styles whose rights are now owned by TRACOM Group and a division of Reed Business Information. Robert Bolton and Dorothy Grover Bolton extended their application to a model of Social Styles management, introducing four subtypes for each style, which are 16 types of social styles. The research with social styles has been implemented in Business but it could be implemented in every area where professionals must deal with people.

Howard Gardner (1983) formulates the theory of the eight multiple intelligences. He also underscores the intrapersonal intelligence of those who stand out for their ability to understand their own emotions and interpersonal intelligence, the one that facilitates interacting with others. There are many studies done and in process nowadays that confirm Gardner 's theory.

\subsection{Authors from this Century}

Daniel Goleman diffuses two variables to take into account emotional intelligence (1995) and social intelligence (2006) whose variable that both share is empathy.

Thus a worker with the highest or emotional and social level shows more empathic ability, therefore, greater ability to create emotional links with others, cause connection and maintaining cordial relations with others to relate, to partner or work with.

Following the model of emotional intelligence of Goleman, those factors gives him partly a natural predisposition and partly an apprenticeship after rubbing in living with others, learning paradigm and social, legal and moral rules that are not written but are respected socio-culturally.

Studies in Business and Education (Bisquerra, 2007), Pacheco \& Fernandez Berrocal (2004), Extremera \& Fernandez Berrocal (2004), etc.) show that the individual with emotional capacity knows his emotions, manage or regulate them, so he achieves balance at work and at home. He has tools too to know the emotions of others, he knows how others feel and often provide emotional advice to others.
There are many programs implemented all over the world about emotional intelligence as the one of EE. UU in schools and laws approved recently in Spain that had a result many programs implemented in private and public schools, colleges and universities. Emotional intelligence it is also been applied in Clinic Psychology and in hospitals by health personnel to help better patients.

The studies on social intelligence are more recent. He who is able to empathize socially knows how to treat others and has the quality of being sensitive to the needs of others (they are people that usually are philanthropists, volunteers or offer their help where they are). Assertiveness, empathy and recognizing needs are three necessary variables to manage social conflict in social life and in business which can cause great economic and human losses in a company.

Finally these two aspects, emotional and social intelligence, give a degree of adaptability to a desirable social life and social networks because if the need it they know how to seek aid for survival and advice to overcome the difficulties that are presented in life.

\subsection{Conclusions}

Emotional intelligence is a term that has emerged as cognitive technique at least in the world of Enterprise, Education, Psychology, Health and somehow was popularized in culture by the practical psychological benefits of for emotional management daily life of oneself and comprehensive look awakening to others.

Social intelligence is more recent, however, it still needs scientific studies and social and cultural implementation with more structures, labor laws, Education programs, etc. by the States. This factor bound to the extensive use that will arrive with Tics using virtual platforms and social networks contribute to a new cultural model, would bring a new society, a new social climate where the man realized that deserves and always seek from target human benefit, the common good, and world would be not ruled only by material wealth per se, of few ambitious men. Knowledge will be placed to serve men in order to achieve a better society.

In developing the emotional climate of human teams we think that it is influenced by two factors: individual psychological profile of the employee or by the social ability and have shown that unfolds with each contributing actors to create certain emotional climate of employer work.

Ultimately it is with the psychological support team which feel the employee and employer to proceed, ie, how they perceive the social tissue, how they perceive the common business goal and how it involves disposing of their creativity and energy. This social capacity, ultimately, leads to employee's 
motivation, performance in the production of the company, and that some companies are distinguished from other human teams and achieving greater economic competitiveness.

Framed in the Knowledge Society the new technologies developed for contributing and adding to the socialization properly used appear to multiply the possibilities of management in companies and knowledge in them.

\section{REFERENCES}

[1] Argyle, M. and Kendon, A. (1967). The experimental analysis of social performance. Advances in Experimental Social Psychology. 3: 55-98.

[2] Aristotle Politics

[3] Bandura, A. (Mary Zaplana, trans.) (1987). Thought and action: Social foundations. Barcelona: Martinez Roca.

[4] Bisquerra Alzina, R., \& Pérez Escoda, N. (2007). Emotional competences. Educación XXI: revista de la Facultad de Educación, (10), 61-82.
[5] Grover R. Bolton \& Bolton D. Social Style / Management Style: Developing Productive Work Relationships.

[6] Carnegie D. (2009) How to Win Friends and Influence People (Spanish Translation), Barcelona: Ellipse.

[7] Extremera, N., \& Fernández-Berrocal, P. (2003). La inteligencia emocional en el contexto educativo: hallazgos científicos de sus efectos en el aula. Revista de Educación, 332, 97-116.

[8] Gardner H. (1994) Frames of Mind, Mexico: Fondo de Cultura

[9] Gardner H. (1987) The theory of multiple intelligences, Mexico: Fondo de Cultura

[10] Goleman D. (1995) Emotional Intelligence Barcelona: Kairos

[11] Goleman D. (2006) Social intelligence Barcelona: Kairos

[12] Merrill, D., Reid, R. (1981) Personal Styles And Effective Performance: Make Your Style Work For You. UK: CRC Press.

[13] Pacheco, N. E., \& Fernández-Berrocal, P. (2004). The role of emotional intelligence in students: empiric data. Revista electrónica de investigación educativa, 6(2).

[14] Thorndike, R. L. \& Stein, S. (1937). "An evaluation of the Attempts to measure social intelligence". Psychological Bulletin (34): 275-284. 